\title{
Antioxidant Activity and Nutritional Value of Roselle Seeds Flour
}

\author{
Karma Bako Rimamcwe and U.D. Chavan* \\ Department of Food Science and Technology, Mahatma Phule Krishi Vidyapeeth, Rahuri, India \\ *Corresponding author
}

\begin{tabular}{|c|c|}
\hline & A B S T R A C T \\
\hline & \multirow{6}{*}{$\begin{array}{l}\text { The outcomes for preliminary investigation on Roselle seed flour revealed appreciable } \\
\text { proximate and mineral compositions suggesting a strong positive correlation between } \\
\text { protein and inorganic mineral contents. This shows that Roselle seed is a dense mineral } \\
\text { source and confirmed that Roselle seed is a rich source of nutrients. The outcomes for } \\
\text { calcium (Ca), magnesium ( } \mathrm{Mg} \text { ), phosphorus (P) and potassium (K) corroborate the } \\
\text { findings reported by previous scientists. The study of anti-nutritional factor showed the } \\
\text { simple process of soaking and germination could have a significant effect in the reduction } \\
\text { of phytate and polyphenols concentration in the seed, as this constituents could forms } \\
\text { complexes with protein and minerals reducing the biological value of the seed. Studies of } \\
\text { free radical scavenging activity on Roselle seed flour pre-treatments showed that the } \\
\text { sprouted treatments had shown an appreciable boost in radical activity verifying an } \\
\text { improved hydrogen donating ability compared to the un-sprouted treatments as control. } \\
\text { Hydroxyl radical is an extremely reactive oxygen species having the capability to modify } \\
\text { almost every molecule in the body. The scavenging potential of sprouted Roselle seed } \\
\text { extract could provide medical application in the production of health food; these free } \\
\text { radicals have been implicated for aging as well as food and chemical deterioration } \\
\text { consequently Roselle can prevent cancer, lower blood pressure and improve the digestive } \\
\text { system in humans. }\end{array}$} \\
\hline Keywords & \\
\hline $\begin{array}{l}\text { Roselle seed flour, } \\
\text { Nutritional value, } \\
\text { Antioxidant } \\
\text { activity, } \\
\text { Antinutritional } \\
\text { factors. }\end{array}$ & \\
\hline Article Info & \\
\hline $\begin{array}{l}\text { Accepted: } \\
\text { 25 March } 2017 \\
\text { Available Online: } \\
\text { 10 April } 2017\end{array}$ & \\
\hline & \\
\hline
\end{tabular}

\section{Introduction}

Roselle (Hibiscus sabdariffa Linn.) is a tropical plant belonging to the Family Malvaceae and widely cultivated for its jute like fiber in India, the East Indies, Nigeria and to some extent in tropical America (Yayock, 1988). A woody sub-shrub growing 7-8 feet $(2-2.5 \mathrm{~m})$ tall, acting as annual or perennial, takes about six months to mature.

The mature plants are highly drought resistant but may require water during dry periods when soil moisture is depleted to the point where wilting occurs. Roselle requires a chalky, loamy and peat-rich soil with $\mathrm{pH}$ of
7.6-9.0; and grows best in weakly alkaline soil (Myfolia, 2016).

The seed plant use for this study belong to the genius Hibiscus with more than 350 specie distributed in tropical and subtropical regions around the world and many are believed to have certain medicinal properties and have been used in traditional medicine for many centuries (Al-Wandawi, 2015). The specie Hibiscus sabdariffa comprises a large number of cultivated types classified broadly into two varieties, $H$. sabdariffa var. sabdariffa and $H$. sabdariffa var. altissima Wester. The former 
is generally bushy and pigmented and cultivated for the edible calyces and the latter a tall growing, un-branched types bearing non-edible calyces and mainly cultivated for stem fiber (Morton, 1987; Abu-Tarboush et al., 1997; Gautam, 2014). Omobuwajo et al. (2000) reported that Roselle seeds are bigger than pearl millet varieties, having an average dimension of 5.21 and $2.81 \mathrm{~mm}$. The seeds are somewhat bitter. However, in Africa, they are ground into meal for human food due to their high protein content. They are also roasted to use as a substitute for coffee (Morton, 1987) and contain a substantial amount of oil that resembles that of cotton seed (Mohammed et al., 2007 and Karma and Chavan, 2016).

Roselle seed oil are richer in carotenoids than expensive oils like niger (Guizotia abyssinica) seed oil (70.2 $\pm 0.03 \mathrm{mg} \beta$-carotene $/ 100 \mathrm{~g})$ and coriander (Coriander sativum) seed oil $(89.2 \pm 0.05 \mathrm{mg} \quad \beta$-carotene $/ 100 \mathrm{~g}) \quad$ (Ramadan and Morsel, 2004). Carotenoids are important ingredients in cosmetic industries due to their antioxidant activity and protective effect on the skin (Platon, 1997). Therefore, Roselle seeds oil has good potential for utilization in the Cosmetic Industry.

The proximate composition of whole Roselle seeds indicated that, seeds contained relatively high fat and protein (as $\% N x 6.25$; $20.97 \%$ and $29.61 \%$ respectively). The physico-chemical parameters of crude oil extracted from Roselle seeds by soaking at room temperature (cold extraction) indicated the oils had 1.4674 refractive index; 0.078 (at $420 \mathrm{~nm}$ ) yellow-greenish colour, $0.78 \%$ acidity, 198.82 saponification value, 97.62 (g of $\mathrm{I}_{2} / 100 \mathrm{~g}$ oil) iodine value; $1.52 \%$ unsaponifiable matter; 4.82 ( $\mathrm{Meq} \mathrm{O}_{2} / \mathrm{Kg}$ oil) peroxide value; $6.21 \mathrm{p}$-anisidine value; and 15.85 totox number. Gas Liquid Chromatography technique has been developed for identification and quantitative determination of total unsaturated and saturated fatty acids. This technology showed that Roselle crude oil had $73.40 \%$ unsaturated and $26.57 \%$ saturated fatty acids respectively. Major fatty acid found was oleic acid (38.46\%) followed by linoleic $(33.25 \%)$ and Stearic (5.79\%). Stability of crude Roselle seed oil against oxidation during the accelerated storage of oil indicated that the crude oil induction period to be 10 days at $65^{\circ} \mathrm{C}$. The relatively high fat content of the seeds and high protein content of resulted meal beside the relatively high oxidation stability of Roselle suggest that Roselle seeds could be a novel and economic source of healthy edible fat and for other food industry applications. In some parts of Africa, the seeds are reported to be used for its oil. The seeds are reported to be rich in proteins, dietary fiber, carbohydrate and fats (AbuTarboush et al., 1997; Rao, 1996; ElAdawy and Khalil, 1994).

Roselle calyces and petals of the flower are extensively used to improve herbal drinks, cold and warm beverages, as well as making jams and jellies (Rao, 1996; Tsai et al., 2002).

The animal proteins are extensively recognized as an important source of affordable proteins but are most times very expensive. In many African countries food from animal source are mainly consumed by households of higher socio-economic status and majority of the population does hardly access these food due to poverty (Al Wandawi et al., 1984). Roselle plants are mostly used in the processing industry for extraction of fiber. Roselle seed is the byproducts of the Roselle processing industry (Bamgboye and Adejumo, 2009). This unwanted byproduct can be recycled as value added food supplements, as it provides advantageous bio-active compounds, good source of edible oil and proteins (Bertagnolli et al., 2014; Nyam et al., 2012). Roselle 
seeds can be ground into fine flour and used for enriching other cereals such as wheat in value added products.

At present, there are very few reports on harnessing the bio-nutritional potential of Roselle seeds in value added products (Nyam et al., 2014). Adding cereals with complementary nutritive profiles, such as Roselle seeds, may yield a more complete enrich food source (Okafor et al., 2002; Arshad et al., 2007; Bala et al., 2015; Wani et al., 2015).

Combining the nutritional value of wheat and Roselle seeds in composite formulations may yield good quality food products with excellent nutritive qualities. Hence, the aim of this study was to investigate the bionutritional viability of Roselle seeds for the benefit of human race with the objective of to study the nutritional quality and antioxidant activity of the Roselle seed flour.

\section{Materials and Methods}

The raw seed materials, ingredients and chemicals used in this study were procured from the local market.

\section{Preliminary studies}

The following preliminary studies on pretreatments where adopted for Roselle seeds.

1. Un-sprouted Whole Roselle Seeds Flour (UWRSF), as Control

2. Un-sprouted Decorticated Roselle Seed flour (UDRSF)

3. Sprouted Whole Roselle Seed Flour (SWRSF)

4. Sprouted Decorticated Roselle Seed Flour (SDRSF)
The pre-treatments were prepared accordingly: both cleaned raw and germinated (sprouted) seeds were divided into two portion each, the first portion was grind whole with a laboratory scale hammer mill and the resulting powder sieved through a 60 mesh screen filter until a fine whole seed powder was obtained; the second portion was coarse grind with sieving intermittently to separate out the bran to obtain a decorticated flour then further grind to a fine mix. The resulting whole and decorticated cleaned (raw and sprouted) seed flour fractions obtained were packed separately in a HDPE bag and stored in a cool dry place until used.

\section{Proximate chemical composition}

The proximate analysis of Roselle seed flour treatments was determined according to AACC (2000). The moisture content was determined by AACC method 08-01, crude protein by Kjeldahl's AACC method 44-15A, lipids content by AACC method 46-13, dry ashing by AACC method 30-25 and gravimetric method AACC 30-25 were used respectively. Total carbohydrates was estimated by difference and calculated as $100 \%-[\%$ (Moisture + Fat + Ash + Protein) $]$ AOAC (2000).

\section{Inorganic mineral analysis}

For exploring the potentials of Roselle seeds, their mineral composition was determined by using the following methods. Macro elements: Calcium ( $\mathrm{Ca}$ ) and magnesium $(\mathrm{Mg})$ where both determined using complex metric titration with potenciometric indicator method as described by El Mahi et al., (1987); potassium (K) was determined by using method described by Knudsen and Peterson (1982); and phosphorus (P) was determined by the method described by Jackson (1973). 


\section{Antinutritional factors}

\section{Phytic acid}

Phytic acid was estimated using the method described my Davies and Hilary (1979), with slight modification.

\section{Total phenols}

Total phenols was estimated with FolinCiocalteu reagent (FCR), the phenols reacts with an oxidizing agent phosphomolybdate in Folin-Ciocalteu reagent under alkaline conditions and results in the formation of a blue coloured complex, the molybdenum is measured at $650 \mathrm{~nm}$ calorimetrically (Bray and Thorpe, 1954).

\section{Antioxidant activity}

2,2-diphenyl-1-picrylhydrazyl (DPPH) radical scavenging capacity was determined according to the method of Liu and Yao (2007) as reported by (Nyam et al., 2012) with slight modifications. $2 \mathrm{~g}$ of sample was shaken on a shaker (Steelmet novatech) in $10 \mathrm{~mL}$ methanol for $1 \mathrm{hr}$ at $120 \mathrm{rpm}$. The mixture was filtered using whatman number 1 filter paper and solvent evaporated at $20^{\circ} \mathrm{C}$ by heating on a soxhlet mantle (Shanti Scientific Industries Mumbai India). To the sample extract obtained $0.5 \mathrm{~mL}$ of ethanol was added to dissolve the fat. From the extract $0.2 \mathrm{~mL}$ sample was mixed with $2.8 \mathrm{~mL}$ ethanol plus $2.8 \mathrm{~mL} 0.004 \% \mathrm{DPPH}$ was added. Control was made in the same procedure using water in the place of water. The mixtures were then shaken vigorously and allowed to stand in the dark for 30minutes at room temperature, and the absorbance measured at $517 \mathrm{~nm}$ against ethanol. The DPPH radical scavenging capacity was calculated using the equation:

$$
\text { Percent inhibition of DPPH activity }=\frac{\text { A - B }}{--------\times 100}
$$

Where: $\mathrm{A}=$ Absorbance of Control; $\mathrm{B}=$ Absorbance of Sample

\section{Statistical analysis}

All experiments were carried out in such a way that the degree of freedom remains more than 12 with suitable replications and treatments. Data obtained in the present study were analyzed by Completely Randomized Design (CRD) as given by Panse and Sukhatme (1967).

\section{Results and Discussion}

\section{Proximate and mineral composition}

The results for proximate and mineral composition of the pre treatments are presented in Table 1 and 2. The results of proximate analysis showed that Roselle seed is a rich source of valuable nutrients (Emmy Hainida et al., 2008; Ishmail et al., 2008). For un-sprouted whole and sprouted whole flour UWRSF and SWRSF respectively the results for protein, lipid, ash (Tounkara et al., 2013; Cissouma et al., 2013); while crude fiber (Nzikou et al., 2011) and total carbohydrate (Emmy Hainida et al., 2008) were in agreements with literature.

However, the results for de-corticated counterparts showed a more improved values for proteins, lipid and ash; suggesting that most valuable nutrients are concentrated in the endosperm. There is a significant difference $(\mathrm{p}<0.05)$ in all the treatments when compared to control. Results show that Roselle seed had a dense mineral source. The outcomes for calcium $(\mathrm{Ca})$, magnesium $(\mathrm{Mg})$, phosphorus $(\mathrm{P})$ and potassium $(\mathrm{K})$ corroborate the findings reported by previous scientists (Rao, 1996; Nzikou et al., 2011; and Cissouma et al., 2013). The results of this treatments are significantly different $(\mathrm{p}<0.05)$ when compared to control, with the decorticated counterparts showing higher values 
also suggesting that most of the minerals are concentrated in the endosperm.

These minerals are essential in preventing deficiency diseases (Cissouma et al., 2013) for example: Calcium is a mineral that is necessary for life. In addition to building bones and keeping them healthy, calcium helps for preventing blood clot; nerves send messages and muscles contract (Nof, 2016). Magnesium plays a very critical role in energy synthesis and storage, as phosphate and magnesium ion interaction makes magnesium essential to the basic nucleic acid chemistry of all cells of all known living organisms; boosting over 300 enzyme actions including all enzymes using or synthesizing ATP and those that use other nucleotides to synthesize DNA and RNA; as ATP molecules are normally found in a chelate with a magnesium ions (Romani and Andrea, 2013); essential for normal function of the heart, kidney, arteries and bone (Sleelig, 1980) and for neuromuscular system (Durlach, 1988). Symptoms of poor magnesium intake include muscle cramps, facial tics, poor sleep, and chronic pain.

\section{Anti-nutritional factor}

Ant-nutritional factors are natural agents in food that limits the bioavailability of nutrients, and to get the best from our food these compounds need to be removed during food processing (Uebersax and Ocean, 2003). Al-Wandawi et al., (1984) and Abu-Tarboush and Ahmed (1996) reported that whole Roselle seeds have a trace of free and bound gossypol compounds, but a higher phytate content than soybean reported by AbuTarboush and Ahmed (1996); however this factors in legumes can to a large extent be eliminated or reduced by manipulation of processing techniques during food preparation to enhance the food value (Mwanja et al., 1999; Giami, 2004; Seema Sharma et al., 2015). In these studies anti-nutritional factors phytates and total polyphenol contents in Roselle seed were reviewed adopting various pre-treatments and the techniques of soaking and sprouting.

\section{Phytate}

Reduction of phytates by soaking and sprouting seeds sends signal to the seeds to release enzymes phytase breaking down phytates to release the phosphorus content. The results of the treatments obtained in the present study are outlined in Table 3. These findings suggested that the process of soaking and sprouting reduce anti-nutritional factor phytate which to large extent affect the protein quality in legumes (Mwanja et al., 1999, Giami, 2004; Seema Sharma et al., 2015). The result showed sprouted treatment had lesser content than the un-sprouted treatments; and the outcomes are significantly different $(p<0.05)$ compared to control.

\section{Total Polyphenol Content (TPC)}

Polyphenols combined with metals and proteins to form complexes reducing the value of food legumes if not properly processed. Total phenolic content (TFC) in Roselle seed was extracted using $80 \%$ ethanol and expressed as $\mathrm{mg}$ Catechol /g of dry sample. For the four treatments, UWRSF recorded (2.23 $\mathrm{mg}$ Catechol/g) highest as control followed by SWRSF $(1.72 \mathrm{mg}$ Catechol/g) while for decorticated seed flours UDRSF recorded (3.51 $\mathrm{mg}$ Catechol/g) highest followed by SDRSF (2.91 mg Catechol/g) respectively, with significant difference $(\mathrm{p}<0.05)$ when compared to control (Table 4.5). 
Table.1 Proximate analysis $(\% \mathrm{db})$ of Roselle seed flour pre-treatments*

\begin{tabular}{|l|c|c|c|c|c|c|}
\hline \multicolumn{1}{|c|}{ Treatments } & Moisture & Protein & Lipid & Ash & Crude Fiber & $\begin{array}{c}\text { Total } \\
\text { Carbohydrate }\end{array}$ \\
\hline UWRSF (control) & 5.66 & 38.06 & 23.80 & 4.40 & 19.87 & 13.87 \\
\hline UDRSF & 5.42 & 48.13 & 28.30 & 5.50 & 6.95 & 11.12 \\
\hline SWRSF & 5.94 & 37.19 & 23.57 & 4.55 & 21.52 & 13.17 \\
\hline SDRSF & 5.34 & 47.25 & 27.84 & 5.92 & 8.50 & 10.49 \\
\hline S.E.( \pm ) & 0.1 & 1.21 & 0.82 & 0.09 & 0.14 & 0.09 \\
\hline CD at 5\% & 0.31 & 3.64 & 2.47 & 0.27 & 0.42 & 0.27 \\
\hline CV $(\%)$ & 3.14 & 4.90 & 5.48 & 3.06 & 1.70 & 1.27 \\
\hline
\end{tabular}

*Each value is an average of six determinations on dry weight basis $(\mathrm{db})$

Table.2 Effect of pre-treatments on mineral composition of Roselle seed flours (mg/100g)*

\begin{tabular}{|l|c|c|c|c|}
\hline Flour Treatments & Calcium $(\mathrm{Ca})$ & Magnesium $(\mathrm{Mg})$ & Phosphorus $(\mathrm{P})$ & Potassium $(\mathrm{K})$ \\
\hline UWRSF (control) & 320.45 & 464.36 & 590.14 & 1925.67 \\
\hline UDRSF & 593.99 & 659.02 & 843.5856 & 2075.33 \\
\hline SWRSF & 328.13 & 469.15 & 592.134 & 1525.27 \\
\hline SDRSF & 616.78 & 664.93 & 849.669 & 1825.45 \\
\hline S.E. $( \pm)$ & 9.36 & 7.48 & 5.42 & 42.72 \\
\hline CD at 5\% & 28.21 & 22.54 & 16.35 & 128.77 \\
\hline CV $(\%)$ & 3.49 & 2.29 & 1.31 & 4.03 \\
\hline
\end{tabular}

*Each value is an average of six determinations on dry weight basis (dwb); NB: UWRSF (Un-sprouted Whole Roselle Seed Flour); UDRSF (Un-sprouted Decorticated Roselle Seed Flour); SWRSF (Sprouted Whole Roselle Seed Flour); SDRSF (Sprouted Decorticated Roselle Seed Flour). 
Table.3 Effects of pre-treatments on phytate and total phnolic contents of Roselle seed Flour*

\begin{tabular}{|l|c|c|}
\hline \multicolumn{1}{|c|}{ Treatment } & Phytate $(\mu \mathrm{g} / \mathrm{g})$ & $\begin{array}{c}\text { Total phenolic content } \\
\text { mg Catechol /g dry weight }\end{array}$ \\
\hline UWRSF (control) & 2.58 & 2.23 \\
\hline UDRSF & 2.30 & 3.51 \\
\hline SWRSF & 2.42 & 1.72 \\
\hline SDRSF & 1.54 & 2.91 \\
\hline S.E. $( \pm)$ & 0.03 & 0.02 \\
\hline CD at 5\% & 0.10 & 0.07 \\
\hline CV $(\%)$ & 2.70 & 1.60 \\
\hline
\end{tabular}

*Each value is an average of six determinations

Table.4 Effects of pre-treatments on Roselle seed flour DPPH free radical test (antioxidant activity)*

\begin{tabular}{|l|c|}
\hline Treatments & $\%$ DPPH activity \\
\hline UWRSF & 69.11 \\
\hline UDRSF & 66.93 \\
\hline SWRSF & 86.60 \\
\hline SDRSF & 85.48 \\
\hline S.E. $( \pm)$ & 0.27 \\
\hline CD at 5\% & 0.81 \\
\hline CV $(\%)$ & 0.61 \\
\hline
\end{tabular}

*Each value is an average of six determinations. NB: UWRSF (Un-sprouted Whole Roselle Seed Flour); UDRSF (Un-sprouted Decorticated Roselle Seed Flour); SWRSF (Sprouted Whole Roselle Seed Flour); SDRSF (Sprouted Decorticated Roselle Seed Flour). DPPH = 2, 2-diphenyl-1-picrylhydrazyl.

Decorticated samples had elevated values than the whole seed counterparts indicating that the phenolic components are concentrated in the endosperm. The reduced values for sprouted treatments in both categories proves that unwanted components can be reduced by the manipulation of processing technique such as soaking and sprouting (Bishnoi and Khetarpaul, 1994; Fernandez et al., 1997; Alonso et al., 2000). The total phenol obtained for the whole seed treatments in this study were in conformity with the results, 1.99 to $1.66 \mathrm{mg} \mathrm{GAE} / \mathrm{g}$ for $30 \%$ acetone and water extract respectively reported by Cissouma et al., (2013). The slight variation may be related to the polarity of solvent type used in the extraction as different solvent will yield different total phenolic contents
(Cissouma et al., 2013). The result obtained in this study confirms the high total phenol content in Roselle seeds.

\section{Antioxidant activity}

The effects of pretreatments on DPPH radical scavenging activity of Roselle seed was investigated, the free radical test is based on the exchange of a proton between the antioxidant and the stable DPPH free radical which shows absorption at $517 \mathrm{~nm}$. The results obtained are outlined in Table 4. Sprouted treatments showed higher radical activity compared to un-sprouted treatments. These results showed that processing treatments change the antioxidant activity of Roselle seed flour. The Roselle seed parts 
also showed different antioxidant activity due to their concentration in that specific part. For maintaining good antioxidant activity minimum processing treatment should be given to the Roselle seeds. The results of the treatments are significantly different $(\mathrm{p}<0.05)$ compared to control.

\section{References}

AACC. (2000). Approved methods of the American Association of Cereal Chemists (10th ed.). St. Paul, MN: Author (methods 08-01, 30-25, 44-15A, 46-13, 54-21, 10-50D).

Abu-Tarboush, H.M. and Ahmed, S.A.B (1996). Studies on karkade (Hibiscus sabdariffa): protease inhibitors, phytate, in-vitro digestibility and gossypol content. Food Chemistry 56, 15-19

Abu-Tarboush, H.M., Ahmed, S.A.B. and Al Kahtani, H.A. (1997). Some nutritional properties of karkade (Hibiscus sabdariffa) seed products. Cereal Chemistry 74, 352-355

Alonso, R., Aguirre, A. and Marzo, F. (2000). Effect of extrusion and traditional methods on antinutrients and in vitro digestibility of protein and starch in faba and kidney beans. Food Chemistry 68, 159-165.

Al-Wandawi, H. (2015). Organic acids composition of different parts of the medicinal plant-Roselle (Hibiscus sabdariffa), Int. J. of Bio. and Pharm. Research; 6(10): 808-813.

Al-Wandawi, H., Al-Shaikhly, K. and AbdulRahman, M. (1984). Roselle seed a new protein source. Journal of Agricultural and Food Chemistry 32, 510-512.

AOAC (2000). Methods of Analysis of Association of Official Analytical Chemistry, methods $985.2918^{\text {th }}$ Edn. Washington, DC.

Arshad, M. U., Anjum, F. M. and Zahoor, T. (2007). Nutritional assessment of cookies supplemented with defatted wheat germ. Food Chemistry, 102, 123-128.
Bala, A., Gul, K. and Riar, C. S. (2015). Functional and sensory properties of cookies prepared from wheat flour supplemented with cassava and water chestnut flours. Cogent Food and Agriculture, 1, 1019815.

Bambgoye, A.I. and Adejumo, O.I. (2009). Physical Properties of Roselle (Hibiscus sabdariffa L.) Seed. Agricultural Engineering International: the CIGR Ejournal. Manuscript 1154.Vol. XI.

Bertagnolli, S. M. M., Silveira, M. L. R., Fogaça, A. D. O., Umann, L. and Penna, N. G. (2014). Bioactive compounds and acceptance of cookies made with Guava peel flour. Journal of food science Technology, 34, 303-308.

Bishnoi, S. and Khetarpaul, N. (1994). Protein digestibility of vegetables and field peas(Pisum sativum). Plant Food for Human Nutrition 46, 71-76.

Bray, H.G. and Thorpe, W.V. (1954). FolinCiocalteu reagent (FCR), the phenols reacts with an oxidizing agent phosphomolybdate in Folin-Ciocalteu reagent under alkaline conditions. Meth. Biochem. Anal. 1, 27-52.

Cissouma, A.I., Tounkara, F., Nikoo, Mehdi, Yang, N. and Xu, X. (2013). Phyico Chemical Properties and Antioxidant Activity of Roselle Seed Extracts. Adv. J. Food Sci. Technol., 5(11):1483-1489.

Davies, N.T. and Hilary, R. (1979). An evaluation of the phytate, Zinc, copper, iron and manganese contents of, and $\mathrm{Zn}$ availability from, soya-based texturedvegetable-protein meat-substitutes or meat-extenders, Rowett Research Institue, Bucksburn, Aberdeen AB2 9SB, Br. J. Nutr. 41, 579-581.

Durlach, J.(1988). Magnesium in Clinical Practice. Libbey Eurotext, London, Paris, pp:360.

El Mahi, H.E., Ibrahim, I.S., Abdel, M., Magid, H.M., and Eltilib, A.M.A. (1987). A simple method for the estimation of calcium and magnesium carbonates in soils. Soil Sci. Soc. Am. J., 51:11521154. 
El-Adawy, T.A. and Khalil, A.H. (1994). Characteristics of roselle seeds as a new source of protein and lipid. Journal of Agricultural and Food Chemistry 42, 1896-1900

Emmy Hainida, K.I.; Amin, I.; Normah, H. and Mohd.-Esa, N. (2008). Nutritional and amino acid contents of differently treated Roselle (Hibiscus sabdariffa L.) seeds, $J$. Food Chemistry 111, 906-911.

Fernandez, M., Aranda, P., Lopez-Jurado, M., Garcia-Fuentes, M.A. and Urbano, G. (1997). Bioavailabilty of phytic acid phosphorus in processed Vicia faba. L. var. major. Journal of Agricultural Food Chemistry 15, 4367-4371

Gautam, R.D. (2014). Roselle-A Lesser-known of medicinal soft drink and food in India. Nat. Prod. Rad. 3(5): 338-342

Giami, S.Y. (2004). Effect of fermentation on the seed proteins, nitrogenous constituents, antinutrients and nutritional quality of fluted pumpkin (Telfaria occidentalis Hook). Food Chemistry 88, 397-404

Ismail, A., Emmy Hainida, K.I. and Halimatul, S.M.N. (2008). Roselle (Hibiscus $\begin{array}{lll}\text { sabdariffa } & \text { L. }) \quad \text { seeds-Nutritional }\end{array}$ Composition, Protein Quality and Health Benefits, Food 2(1), 1-16.

Jackson, M.L.(1973). Soil Chemical analysis, Prentice Hall of India, Pvt. Ltd., New Delhi pp. 498

Karma Bako Rimamcwe and Chavan, U. D. (2016). Physical properties and nutritional potentials of Indian Roselle (Hibiscus sabdariffa L.) seeds. International Journal of Current Research. 8 (9): 38644-38648.

Knudsen, D. and Peterson, G.A. (1982). Lithium, sodium and potassium. P 225246. In A.L. Page. (Ed.) Methods of soil analysis. Aronomy monogram No. 9, Am. Soc. Agron. Inc., Soil Sci. Soc. Am Inc. Publisher, Madison, Wisconsin, USA.

Liu, Q. and Yao, H. (2007). Antioxidant activities of barley seed extracts. Food Chem 102: 732-737

Mohammed, R., Fernendez, J., Pineda, M. and Aguilar, M. (2007). Roselle (Hibiscus sabdariffa) seed oil is a rich source of gamma tocopherol. J. Food Sci. Vol. 72, pp. 207-211.

Morton, J.F. (1987). Roselle, In: Fruits of Warm Climates, Florida Flair Books, Maimi, USA, pp 281-286

Mwanjala, A.M., Kharidah, M., Jamilah, B. and Yaakob, B. (1999). Effects of isolation technique and conditions on the extractability, physicochemical and functional properties of pigeonpea (Cajanus cajan) and cowpea (Vigna unguiculata) protein isolates. I. Physicochemical properties. Food Chemistry 67, 435-443

Myfolia.com(2016), online source: https://myfolia.com

Nof (2016). National Osteoporosis Foundation, $25118^{\text {th }}$ Street S, Suite 630, Arlington, VA, 22202-1 (800) 231-4222. https://www.nof.org/patients/treatment/ca lciumvitamin_d/

Nyam KL, The YN, Tan CP and Kamariah, L., (2012). In vitro Antioxidant Activities of Extract and Oil from Roselle (Hibiscus sabdariffa L.) Seed against Sunflower Oil Autoxidation, Mal J Nutri 18(2): 265274.

Nyam, Kar-Lin; Leao, Sod-Ying; Tan, ChinPing; and Long, Kamariah (2014). Functional Properties of Roselle (Hibiscus sabdariffa L.) seed and its application as bakery product, J. Food Sci. Technol 51(12):3830-3837.

Nzikou, J.M.,Bouanga-Kalou, G., Latos, L., Ganongo-Po, F.B., Mboungou-Mboussi, P.S., Moutoula, F.E., Panyoo-Akdowa, E., Silou, T.H., and Desobry, S. (2011). Characteristics and Nutritional Evaluation of Seed oil from Roselle (Hibiscus sabdariffa L.) in Congo-Brazzaville, Current Research Journal of Biological Sciences 3(2): 141-146.

Okafor, J. N., Ozumba, A. U. and Solomon, H. M. (2002). Production and acceptability of chinchin fortified with oyster mushroom. Nigeria Food Journal, 18, 19-20.

Omobuwajo, T.O., Sanni, L.A. and Balami, 
Y.A. (2000). Physical properties of sorrel (Hibiscus sabdariffa) seeds. Food Engineering 45, 37-41.

Panse, V.G. and Sukhate, P.V. (1985). Statistical methods for Agricultural Workers. $4^{\text {th }}$ ed., New Delhi

Platon, JF. (1997). Lipids in Cosmetology. Ol. Corps Gras Lipid; 4: 275-281.

Ramadan M.F. and Morsel J.T. (2004). Oxidative stability of black cumin (Nigella sativa L.), coriander (Coriandrum sativum L.) and niger (Guizotia abyssinica Cass.) crude seeAd oils upon stripping. Eur J Lipid Sci Technol; 106: 35-43.

Rao, P.U. (1996). Nutrient composition and biological evaluation of mesta (Hibiscus sabdariffa) seeds. Plant Food for Human Nutrition 49, 27-34.

Romani, S. V. and Andrea, M.P. (2013). "Chapter 3. Magnesium in Health and Disease". In Astrid Sigel; Helmut Sigel; Roland K.O. Sigel. Interrelations between Essential Metal Ions and Human Diseases. Metal Ions in Life Sciences 13. Springer. Pp.49-79.

Seema Sharma, Dharmesh, C. Saxena and Charanjit, S. Riar (2015). Analysing the effect of germination on phenolics, dietary fibres, minerals and $\gamma$-amino butyric acid contents of barnyard millet (Echinochloa frumentaceae), Food
Bioscience. 13(3): 287-293.

Sleelig, G.F. (1980). Noncatalytic subunits of human bllod plasma coagulation factor XIII. Preparation and partial characterization of modified forms. J.Biol. Chem., 255918: 8881-8886.

Tounkara, F., Amza, T., Lagnika, C., Le, G. and Shi, Y. (2013). Extraction, characterization, nutritional and functional properties of Roselle (Hibiscus sabdariffa Linn) seed proteins. Songklanakarin J. Sci. Technol. 35(2), 159-166.

Truswell, A.S. (2002). Cereal grains and Coronary heart disease. European Journal of Clinical Nutrition 56, 1-14

Uebersax, M.A. and Occena, L.G. (2003). Legumes: Legumes in Diet. In: Caballer B, Trugo LC, Finglas PM(EDs) Encyclopedia of Food Sciences and Nutrition, $\left(2^{\text {nd }} E d n\right)$, Academic Press, Amsterdam, pp 3520-3534

Wani, S. H., Gull, A., Allaie, F., and Safapuri, T. A. (2015). Effects of incorporation of whey protein concentrate on physicochemical, texture, and microbial evaluation of developed cookies. Cogent Food and Agriculture, 1, 1092406.

Yayock, J.Y., Lombin, G. and Owonubi, J.J. (1988) Crop Science and Production in Warm Climates. Macmillan Publishers, London, p.307.

\section{How to cite this article:}

Karma Bako Rimamcwe and U.D. Chavan. 2017. Antioxidant Activity and Nutritional Value of Roselle Seeds Flour. Int.J.Curr.Microbiol.App.Sci. 6(4): 2654-2663. doi: https://doi.org/10.20546/ijcmas.2017.604.309 